\title{
Effect of Puccinia silphii on Yield Components and Leaf Physiology in Silphium integrifolium: Lessons for the Domestication of a Perennial Oilseed Crop
}

\author{
M. Kathryn Turner ${ }^{1}$, Damian Ravetta ${ }^{2}$ and David Van Tassel ${ }^{1, * \text { (D) }}$ \\ 1 The Land Institute, 2440 E. Water Well Rd, Salina, KS 67401, USA; turner@landinstitute.org \\ 2 National Scientific and Technical Research Council (MEF-CONICET), Fontana 140, Trelew 26035, Argentina; \\ ravetta@agro.uba.ar \\ * Correspondence: vantassel@landinstitute.org; Tel.: +1-(785)-823-5376
}

Received: 10 February 2018; Accepted: 1 March 2018; Published: 5 March 2018

\begin{abstract}
New crops with greater capacity for delivering ecosystem services are needed to increase agricultural sustainability. However, even in these crops, seed yield is usually the main criteria for grain domestication. This focus on yield can cause unintended structural and functional changes. Leaves of selected plants tend to be more vulnerable to infection, which can reduce performance, assimilates, and ultimately yield. Our objectives were to determine the impact of rust (caused by Puccinia silphii) on yield and leaf function in selected Silphium integrifolium (Asteraceae) plants. We tested the effect of a fungicide treatment on rust severity and yield, compared the rust infection of individuals in a population selected for yield, and related this to chemical changes at the leaf level. We also estimated heritability for rust resistance. We found that productivity indicators (head number and weight, leaf weight) and leaf processes (photosynthetic capacity, water use efficiency) were reduced when silphium leaves and stems were more heavily infected by P. silphii. Leaf resin content increased when susceptible plants were infected. Fungicide treatments were effective at reducing rust infection severity, but were ineffective at preventing yield losses. We propose that disease resistance should be included early in the selection process of new perennial crops.
\end{abstract}

Keywords: disease control; new crops; rust; resin; photosynthesis; gas exchange

\section{Introduction}

Although diseases and herbivory are key factors in determining yield in crops, the process of the domestication of wild plants has been generally analyzed in terms of yield and yield components and less in terms of specific disease resistance or the potential factors contributing to the resistance. During early stages of domestication in seed crops, disease resistance tends to be captured only as it affects seed yield and potentially persistence in perennial crops. Unintended structural and functional changes can occur together with yield increase, and there is recent evidence of anatomical and functional changes at the leaf level that occur very early in the domestication process [1]. Structural and functional changes resulting from the selection for yield, such a leaf thickness, cell size, and secondary metabolites (i.e., resins) are traits known to influence the response to pathogens [2-4]. Among a group of new perennial grain crops under domestication, Silphium integrifolium Michx. (silflower, silphium, rosinweed) has been selected as a new dual use oilseed and biomass crop [5]. Silphium is native to central and eastern North America and was selected for domestication primarily due to its drought tolerance and high seed oil content.

Rust caused by Puccinia silphii [6] is likely to be an important disease in the development of silphium. Puccinia silphii is a microcyclic fungal pathogen producing only the hyaline basidiospore and over-wintering teliospore, and lacking the haploid pychniospore, dikaryotic aeciospore, and the 
long-distance dispersing urediniospore stages of macrocyclic rusts [7]. It has been the most prevalent disease in introductory plantings and breeding plots in central Kansas, although powdery mildew (caused by Erysiphe cichoracearum), downy mildew (caused by Plasmopara halstedii), and stem spotting (caused by Alternaria alternate) have also been observed. Between 2003 and 2013 there were very few pests or diseases observed in silphium research plantings in Kansas. The low initial levels of rust incidence may have been due to limited local sources of inoculum when the populations of silphium were small in research plantings and inoculum was spreading from dispersed native stands. In 2014, high moisture promoted the spread of rust from a densely planting stand of silphium to many of the other plots. By 2015 many silphium plants failed to flower or produced very small, late flowers. Some of these individuals had necrosis on the apical meristem or entire length of the stalk, and others had severely stunted plant height. These symptoms have persisted in subsequent years and prompted interest in determining the impact of rust on the yield and physiology of silphium.

Rust-causing pathogens are detrimental to biomass production and grain yield across many economically significant crops. Puccinia triticina Eriks, which causes leaf rust in wheat (Triticum aestivum), durum wheat (T. turgidum L. var. durum), cultivated emmer wheat (T. dicoccon), and wild emmer wheat (T. dicoccoides), Aegilops speltoides, goatgrass (Ae. cylindrica), and triticale (X Triticosecale) [8] reduces the photosynthetic capacity of the flag leaf and lower leaves as it utilizes assimilates that would be translocated to developing grain, resulting in lower seed set and smaller kernel weight [8]. The quality of the grain can also be affected. Decreased protein content and increased yellow pigmentation have been observed in infected grain [8-10] but vary by genotype and environment [11]. Changes in photosynthesis due to foliar pathogens have been reported across a range of crop species including leaf rust (Puccinia hordei Otth.) in barley (Hordeum vulgare L.) [12], powdery mildew (Eysiphe polygoni DC) in sugar beet (Beta vulgaris L.) [13], and rust (Uromyces appendiculatus), angular leaf spot (Phaeoisariopsis griseola (Sacc.) Ferr.), and anthracnose (Colletotrichum lindemuthianum) in common bean (Phaseolus vulgaris L.) [14]. Besides reduction in photosynthesis, infections can cause other physiological changes such as reduced water use efficiency, as observed in powdery mildew (Uncinula necator) in grape (Vitis vinefera and V. labruscana) [15] and powdery mildew (Puccinia lagenophorae) in groundsel (Senecio vulgaris) under drought conditions [16].

Our objectives here were to determine the impact of silphium rust on plant yield and leaf function. We compared the rust infection of individuals in a population of plants selected for yield and related this to chemical changes at the leaf level. We also estimated heritability for rust resistance and tested the effect of a fungicide treatment on rust severity and yield.

\section{Materials and Methods}

\subsection{Susceptible and Resistant Plant Materials}

We adapted the Puccinia helianthus disease scales developed by Gulya (1990) [17] and Sackston (1962) [18] to quantify P. silphii percent severity (proportion of the total leaf area infected) and response (a measure of pustule size and vigor), on the leaves and stems of silphium plants. The pictorial scales for severity and response (Supplementary Materials Figure S1) were used in July 2015 to identify individuals with high and low disease levels, which were used as susceptible and resistant checks, respectively. The determination of resistance and susceptibility was based on our observations of infection caused by naturally occurring pathogen populations in our breeding nurseries. We are not aware of any description of $P$. silphii races, differential reaction to various isolates, or silphium genotypes evaluated for resistance to $P$. silphii. Resistant plants ( $\leq 1 \%$ severity of infection on the leaves) included SI1100, SI1066, and SI1830. Susceptible plants ( $>2 \%$ leaf severity) included SI591, SI1619, and SI175. In 2015, very few flowering heads were produced by SI1066, SI1830, SI1619, and SI175. These individual genets were identified from a large breeding nursery of over 7000 genets from 100 half-sib families planted approximately $1 \mathrm{~m}$ from each other in 2013. Rust symptoms were seen on the edges of this plot in 2014 and by 2015 the vast majority of plants in the nursery were infected. 
Check genets were replicated by digging and dividing crowns in December 2015. Cloned rhizomes were placed in pots containing soilless potting medium and allowed to regrow in a greenhouse prior to transplanting in the spring of 2016.

\subsection{Fungicide Experiment}

To test whether fungal pathogens P. silphii, E. cichoracearum, and P. halstedii were causing necrosis and yield losses, we designed a randomized block trial in a field planted in 2014 that had experienced severe stalk necrosis and natural infection by rust, powdery mildew, and downy mildew, observed in 2015. Each block contained 15 existing randomly selected individuals and eight replicated checks with three reps of each treatment; inoculum was produced by natural infection. The checks included two Helianthus annuus accessions from the USDA's (United States Department of Agriculture) National Plant Germplasm System (HA-89 and HA-292), three resistant, and three susceptible Silphium integrifolium genets from the checks described above. H. annuus accessions were planted from seed and S. integrefolium genets were transplanted from clones on 26 April 2016. Two treatments, fungicide and water control, were replicated three times, and applied every 3 weeks through flowering, following the manufacturer's application rate for Puccinia species $\left(1.2 \mathrm{~g} / \mathrm{m}^{2}\right)$. The water applied to the control treatment was equal in volume to the fungicide application. No water treatment was applied at the time of the initial fungicide application. Azoxystrobin (Heritage ${ }^{\circledR}$, with the active ingredient methyl (E)-2-\{2-[6-(2-cyanophenoxy)pyrimidin-4-yloxy]phenyl\}-3-methoxyacrylate) was selected based on its recommended use in controlling rust in H. annuus production [19], as well as powdery and downy mildews.

The measurements of rust percent severity of infection and response (pustule size and vigor) on the leaves (Supplementary Materials Figure S1) were recorded based on visual observations on three dates in the summer, at least one week after fungicide or water application. Clonal checks were subsequently used to calculate heritability on an entry mean basis as described by Fehr (1987) [20]. The number of stalks per plant, stalks with complete necrosis or necrosis of the meristem, and the number of capitula per stalk were counted on one date between the stages of seed fill and senescence. At maturity, three stalks per plant were harvested and weighed. The capitula, leaves, and stems from a subset of plants were dried to obtain the mean moisture content of each organ. The fresh weights were multiplied by the coefficient: 1 -percent moisture, to estimate dry weight. Biomass from the leaves ( $n=57$ plants), stems $(n=57)$, and capitula (including seeds and the receptacle, $n=173$ ) were weighed separately.

Prior to flowering in June 2016, we measured gas exchange at the leaf level on a subset of the experimental entries with $0.1,0.5,1,2$, and $5 \%$ severity of the leaf area infected. Each severity class was represented by measuring three fully expanded leaves from six plants, except the uncommon $5 \%$ disease severity class which was only represented by two plants. To measure $\mathrm{Net}^{\mathrm{CO}_{2}}$ uptake (A) and transpiration (E), we used a portable- infrared gas analyzer (LCA-4, ADC, Hogdesdon, UK). We measured gas exchange on fully developed leaves of same age (last fully developed leaf on a stalk). We recorded the severity of rust infection in each of the leaves on which gas exchange was measured. Leaves were exposed to full radiation and measurements were done on a sunny day between 11 AM and 2 PM to avoid environmental self-shading and provide reliable comparable estimations of gas exchange. Water use efficiency (WUE) was estimated by dividing net $\mathrm{CO}_{2}$ uptake by transpiration. Unless specified, all results represent the experimental lines and do not include the checks.

\subsection{Leaf Resin Content}

In August 2017, we identified several plants in a breeding nursery (established from seedlings in the spring of 2015) that typified either strong or weak partial-resistance to rust. Leaves were harvested from individual plants, dried, and ground for resin extraction. We harvested infected and uninfected leaves both on plants that had a low level of infection (resistant) and a high level of infection (susceptible), which was defined based on the severity of infection on the whole plant based 
on natural infection. Plants were considered susceptible if more than $50 \%$ of the leaves were infected at a severity of $\geq 1 \%$; and resistant if rust was present on less than $20 \%$ of the leaves at a severity of $<1 \%$. Leaf resin was extracted using dicloromethane (DCM) in a Soxhlet apparatus for $6 \mathrm{~h}$ until exhaustion [21]. DCM extracts were weighed and resin content was estimated on a dry-weight basis. The term "resin" is used to describe a complex mixture of non-polar secondary metabolites, mostly but not uniquely terpenes (sesqui- and diterpenes) [22]. They are extracted with non-polar organic solvents such as dicloromethane. Resins are common in many species of Asteraceae, thus the common name rosinweed of several species in the family.

Treatment differences were tested using an ANOVA and Tukey's test for mean separation from the R package 'laercio' and correlations were tested using the Pearson's correlation coefficient in the R base package [23].

\section{Results and Discussion}

We found a range of rust infection severity in silphium plots growing in Central Kansas, from $0-20 \%$ infection. Rust severity increased through the growing season and was highest in June (Figure 1a). The peak level of disease occurring in June may have been due to a reduction in relative humidity and rainfall, which are important to rust disease development [24], causing leaves formed later in the growing season to have lower levels of infection. The fungicide-treated plots were significantly lower in rust disease severity in May and June, but were not significantly different in July (Figure 1a). Only minimal control of infection was attained with fungicide. As the plants grew through the season and the canopy became denser it was not possible to obtain complete fungicide coverage, which may have accounted for the decrease in control efficiency throughout the season. The water control was applied because higher moisture, especially in the form of light mist as in the fungicide application, could promote spore germination and higher disease levels. High humidity is required and is the most important factor for basidiospore germination; basidiospores are very sensitive to desiccation caused by low humidity or direct sunlight; germination can also be inhibited by free water [24]. However, the absence of the first water control treatment did not prevent significant treatment differences in the first ratings in May and even with lower moisture the control plots had higher infection (Figure 1a). Powdery and downy mildew infection was minimal, including in the control plots, and was thus not recorded.

The H. annuus accessions were not infected with rust during the trial (Figure $1 \mathrm{~b}$ ). The host range of P. silphii is highly specialized and limited to the Silphium genus [25]. The silphium cloned checks exhibited a large range of infection from 0 to $17 \%$ average severity. Although treatment differences were not significant, probably due to the small number of treatment replicates (three) for each cloned check, generally the fungicide-treated plot appeared to have lower infection levels even for the more resistant genets (Figure 1b). These results indicate that a high amount of variation is available for selection within the breeding populations and that fungicide may be able to modestly decrease the severity of infection even in resistant genets. SI1066 was selected as a resistant individual in 2015, but in 2016 had higher infection rates between $2 \%$ and 10\% severity in two of the control treatment plots. In 2015, this individual had the higher infection level compared to the other resistant checks ( $1 \%$ severity) but may have partially escaped severe rust infection due to some other disease or insect pressure that also prevented it from flowering, or its most heavily infected leaves may have been lost to senescence by the time of selection in July.

We found the heritability of percent severity to be moderately high. The heritability on an entry mean basis, as described by Fehr [20], was 0.54 when rust severity was measured in May and 0.60 when measured in June. The moderately high level of heritability will facilitate improvement through the selection of superior genotypes with low disease levels that can be inherited by the next generation. The clonally replicated genotypes used to calculate heritability were also used as checks in the fungicide experiment. As expected, because these were genotypes with extreme phenotypes, the susceptible checks exhibited more severe infection (Figure 1b). 
a)

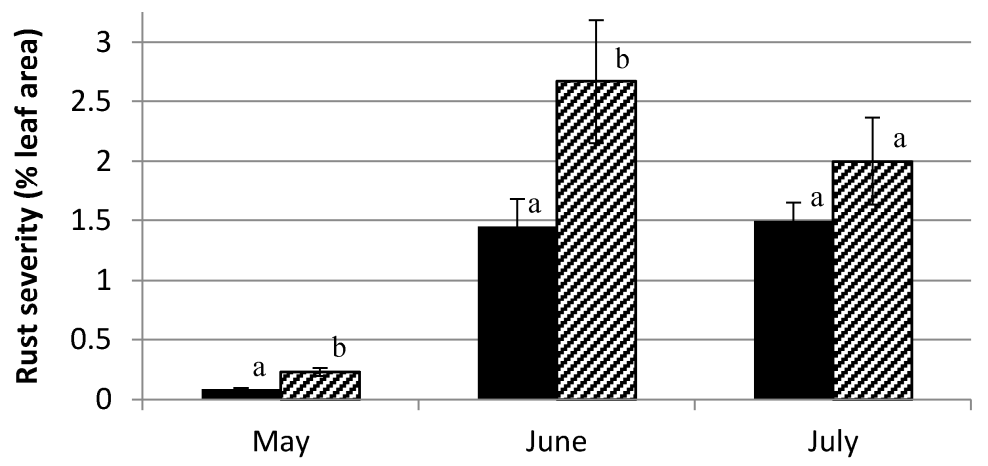

b)

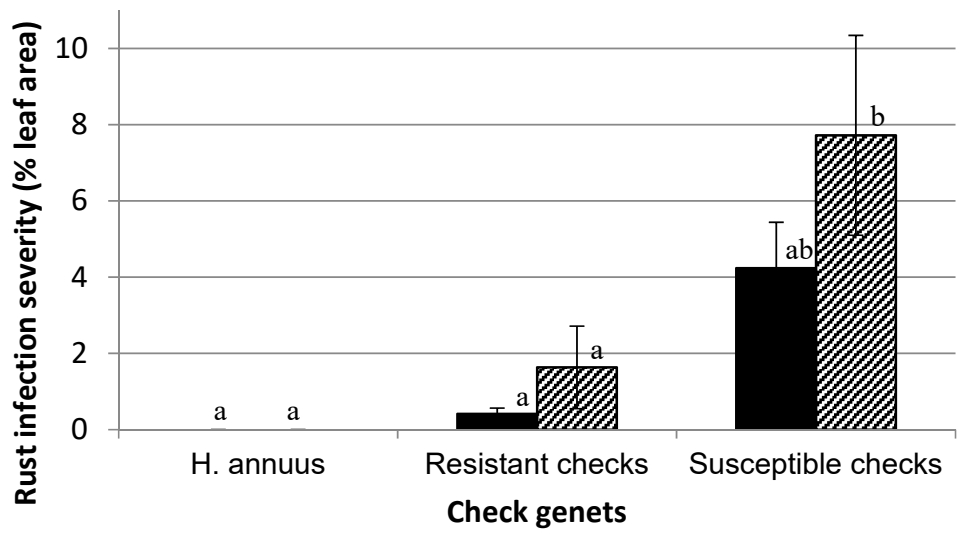

Fungicide $\square$ No treatment

Figure 1. Effect of fungicide application on silphium rust infection. Treatments included Fungicide (Azoxystrobin (Heritage ${ }^{\circledR}$ ) (solid bars) and No treatment, a water application of the same volume as the fungicide (diagonal line bars). Effect was measured as the percent rust severity on individual leaves. Bars represent mean \pm S.E. (a) Rust severity was measured in May, June, and July on experimental plants. (b) Average infection in June of check genets from three individual plant replicates for each treatment. Resistant checks included SI1100, SI1830, and SI1066. Susceptible checks included SI-1619, SI591, and SI175. H. annuus included HA-89 and HA-292. Mean comparisons were made using a Tukey HSD (honest significance difference) test.

Stalks with meristem or complete necrosis occurred on average in $11.9 \%$ (SE $=1.7 \%$ ) of plants in the treated plots and $19.1 \%(\mathrm{SE}=3.2 \%$ ) in the control plots. Interestingly, rust severity in June was weakly to moderately, but significantly, correlated with meristem necrosis $\left(\mathrm{r}^{2}=0.34, p<0.05\right)$ (Figure 2a) suggesting that rust caused by $P$. silphii might have contributed, although it was not the only cause of stem damage. It has been previously predicted that Lygus lineolaris (Palisot de Beauvois; Hemiptera: Miridae) bugs cause meristem damage [26] because as they feed, they secrete an enzyme that causes the necrosis and abscission of reproductive structures [27].

Significant negative correlations were observed between the rust response in June and the yield components including number $\left(\mathrm{r}^{2}=-0.23, p<0.05\right)$ and weight $\left(\mathrm{r}^{2}=-0.28, p<0.05\right)$ of capitula (Figure $2 b)$ as well as the stem rust severity and total leaf weight $\left(\mathrm{r}^{2}=-0.30, p<0.05\right)$ (Figure $2 \mathrm{c}$ ). These results indicate two ways in which rust may limit yield in silphium: first, infection on the stem (meristem necrosis, associated with rust damage) may limit the production of new leaves and thus reduce total leaf area of the plants and number of capitula; additionally, that infection on the leaves themselves may limit the current total $\mathrm{CO}_{2}$ uptake and thus carbohydrate availability for the growth of the capitula, resulting in smaller capitula. The number of capitula, dry weight of leaves, stems, 
and capitula were similar in the fungicide-treated and control plots $(p=0.07-0.25)$. Despite significantly reducing infection in June when plants were at full bloom (Figure 1a), the effects of rust on yield could not be controlled by fungicide applications.

a)

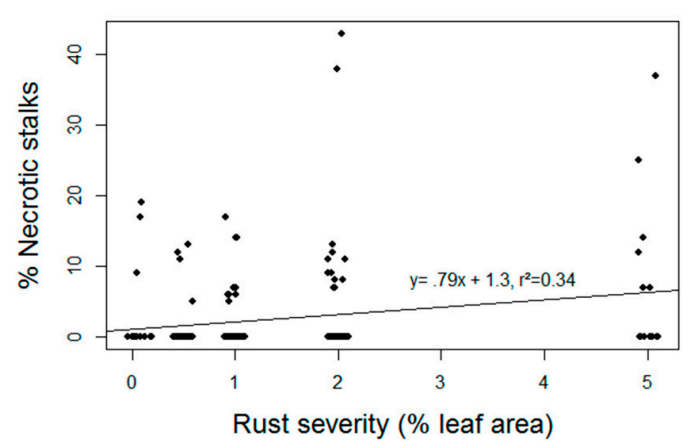

c)

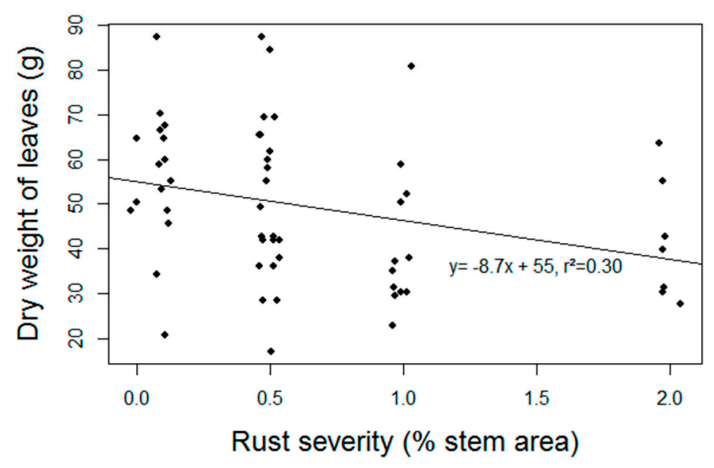

b)

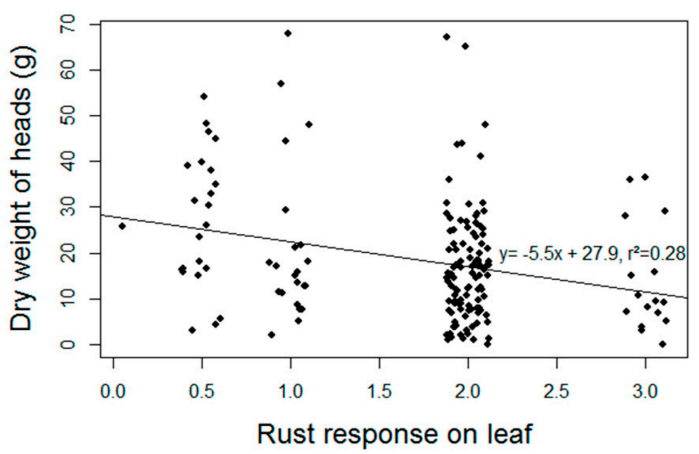

Figure 2. Yield components with rust infection. (a) Percent necrotic stalks from individuals differing in rust severity on the leaf; (b) dry weight of heads (capitula) from individuals differing in rust response on the leaf; (c) dry weight of leaves from individuals differing in rust infection severity on the stems. Points were jittered to distinguish overlapping observations. $r^{2}$ represents the Pearson's coefficient of correlation.

Rust negatively affected $\mathrm{CO}_{2}$ uptake (Figure 3a) while transpiration (E) was not dependent on the level of infection (Figure 3b). Net $\mathrm{CO}_{2}$ uptake decreased by approximately three-fold from a $0.1 \%$ to a $2 \%$ level of disease severity on the leaves and decreased approximately $50 \%$ from a $0 \%$ to a $1 \%$ level of rust severity (Figure 3a). We found that infection in a relatively small area of the leaf had a very large impact on the photosynthetic capacity of the entire leaf (Figure 3a). Because of the different response of assimilation rate (A) (assimilation decreased with rust) and transpiration (E) (transpiration was unaffected by rust, Figure 3b), water use efficiency (WUE) followed a negative response curve, similar to that of A, as rust severity increased (Figure 3c). Some studies have found that $\mathrm{CO}_{2}$ uptake was reduced due to lower photosynthetic capacity in the leaf area between rust pustules [12], which was attributed to the reduced activity of Rubisco in the remaining healthy areas of the leaves [14]. Leaf rust reduced net $\mathrm{CO}_{2}$ uptake at light saturation through reductions in gross photosynthesis rather than through increases in dark respiration rate in wheat [28] and barley [29]. In silphium, we do not know the cause of the reduction in $\mathrm{CO}_{2}$ uptake; there could be a reduction in chlorophyll content, a physical inhibition or shadowing effect of the rust lesions, or a reduction in carboxylation. We hypothesize that stomatal limitation is probably not the cause of the reduction in $\mathrm{CO}_{2}$ uptake, since transpiration was not affected by rust severity; this opens a new question for future research. 
a)

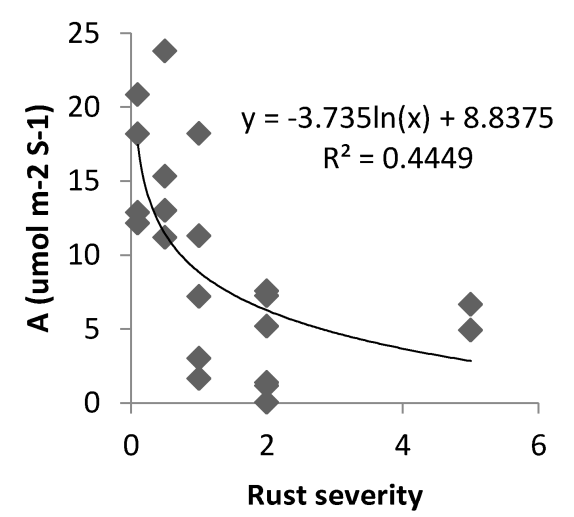

c)

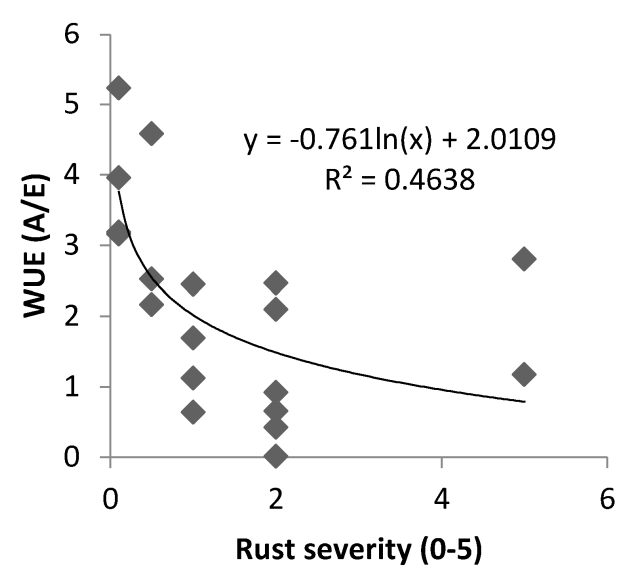

b)

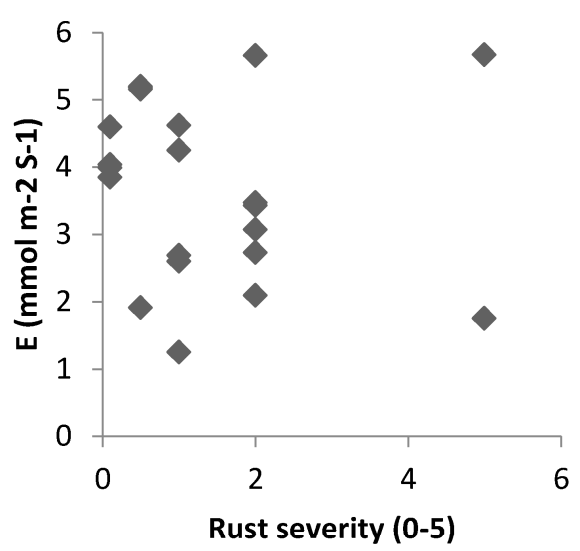

Figure 3. Instantaneous gas exchange from leaves with different levels of rust infection. (a) Net $\mathrm{CO}_{2}$ assimilation rate (A) for fully expanded silphium leaves differing in severity of rust infection; (b) transpiration (E); (c) water use efficiency (WUE). Each data point represents one leaf per plant. Gas exchange was measured at noon (12:00 a.m. to 2:00 p.m.) on a sunny day on fully expanded leaves, exposed to full-sun radiation, using an infrared gas analyzer. In (b), the relationship between $\mathrm{E}$ and rust severity was not significant, therefore no trend line was fitted.

DCM (dicloromethane) extracts, a proxy for total resin content, averaged approximately $8.5 \%$ of the dry weight in non-infected leaves (non-infected leaves and leaves with very low infection of $0.1 \%$ severity) of both susceptible and resistant plants (Figure 4). Leaves infected with a severity of $\geq 1 \%$ accumulated more resin than non-infected leaves on the same plant (Figure 4). At the time when leaves were collected for resin analysis, some of the younger leaves appeared uninfected while others were infected. Presumably the difference in infection was caused by a latent period of disease development following humid microclimate conditions required for spore germination. Terpenes, such as resins and essential oils, are common in members of the Asteraceae [22], most of which are known to have antibacterial, antifungal, and anti-herbivory effects [30,31]. Resin content is dependent on C:N ratios and can be triggered by external stimuli such as resource availability, herbivory [32], and disease infection [33,34].

These results support the hypothesis that resins are involved in the response to rust, but do not directly support the hypothesis that elevated resin content protects plants from infection. One interpretation of this result is that Puccinia elicits plant resin production for its own benefit. Maize biotrophic fungi have, for example, been shown to upregulate anthocyanin biosynthesis, presumably to limit the substrates available for more effective defense responses [35]. Another interpretation is that plants are triggered to synthesize resins after infection to limit the success 
of secondary infections [36]. A final possibility is that the domestication process has resulted in lower baseline but more plastic allocation to resins. Higher resin content in wild compared to selected plants has been observed in silphium [6]. Likewise, domesticated sunflowers produce fewer sesquiterpene lactone-containing trichomes than wild accessions, although investment appeared to be constitutive, not plastic [37]. Low resin production prior to infection may have made our selected populations more susceptible to rust, although some rare individuals have resistance genes or physical/chemical defenses independent of resins. When our breeding populations were small, the population of rust was also small. In this environment, the reallocation of resources towards sexual reproduction could have favored a more inducible resin response. Although our results show that resin levels can increase markedly upon infection, in this case, the induced response may have been too small in magnitude or too late to reduce infection.

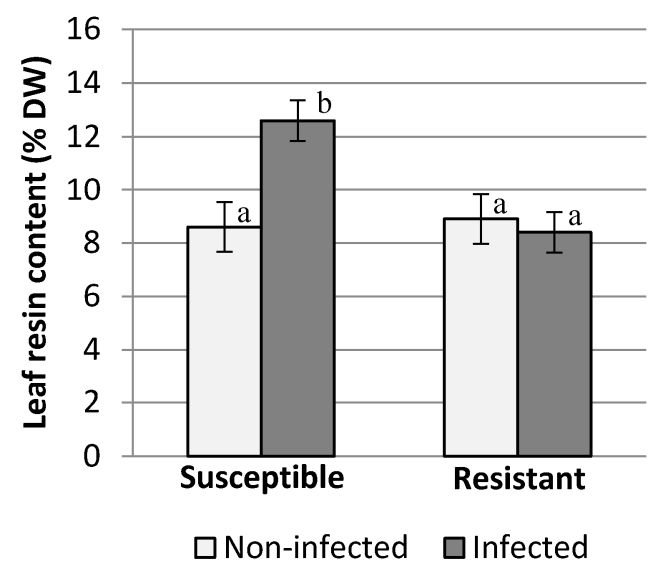

Figure 4. Resin content for non-infected and rust infected leaves from plants that were resistant and susceptible to rust. Rust severity on infected leaves was $\geq 1.0 \%$ for susceptible plants and between 0.1 and $1.0 \%$ for resistant plants. Error bars represent the mean $\pm \mathrm{SE}(\mathrm{F}=5.97, p<0.01)$. Mean comparisons were made using a Tukey HSD test. DW is dry weight.

\section{Key Outcomes and Future Directions}

As in many agriculturally significant crops, we have verified that rust infection causes severe damage in silphium. We found that leaf processes (gas exchange: net $\mathrm{CO}_{2}$ uptake and water use efficiency), and productivity indicators (head number, head weight, and leaf weight) were reduced when silphium leaves and stems were more heavily infected by P. silphii. Although rust severity increased, on average, between May and June and even in July plants exhibited a wide range of damage. A few individuals appeared to be resistant. Many others appeared to be susceptible but able to limit rust and still produce capitula and seeds. These results are consistent with the existence within the silphium breeding population of both complete protection likely conferred by major-effect resistance genes (e.g., "R-genes",) and incomplete resistance genes conferred by multiple genes of partial effect [38]. Further evaluation will be needed to determine the types of resistance in silphium, which may be polygenic, partial, or growth stage-dependent. With the high heritability observed for resistance to rust, selecting for resistant plants is a promising strategy for decreasing rust infection in the population.

We present preliminary evidence that leaf resin content increases when susceptible plants are infected with rust. Infected leaves from plants with generally mild symptoms (resistant plants) do not show elevated resin content. To understand these differences, a deeper understanding of other defense mechanisms in the more resistant plants is needed. Of particular interest is the potential presence of resistance genes and how those genes function to prevent infection. The effect of resins in limiting rust and other pathogens or insect pests is an additional area of interest. 
Controlling rust using fungicides may be practical for particularly high-value plants (e.g., research populations) or to improve seedling survival and rate of establishment. However, even though the fungicide used in this experiment was effective at reducing rust severity, it was ineffective at preventing yield losses. We believe the fungicide application in our experiment was largely ineffective later in the growing season because the canopy structure of silphium makes it very difficult to achieve complete leaf coverage, especially as the plants rapidly increase in number of nodes and plant height in June. It is possible that fungicides with different active ingredients or more complete coverage might be more effective. It appears that, in the absence of total control, P. silphii can rapidly reproduce and re-infect new growth.

\subsection{Priorities for Achieving Future Progress}

Taken together, the leaf functional responses to P. silphii appear to be non-linear, such that while extremely mild symptoms may prove to be economically acceptable, intermediate and severe symptoms are both associated with serious depression of $\mathrm{CO}_{2}$ uptake. At the same time, leaf transpiration is not reduced, suggesting that stomatal conductance remains high. Combined with the elevated synthesis of resins, the reduction of $\mathrm{CO}_{2}$ uptake means that infected leaves likely become net carbon sinks. Increased susceptibility to other forms of stem and meristem damage further compound the effects of intermediate and severe infection.

We have seen very little short-term silphium mortality due to rust infection and we have not found evidence that rust causes severe lodging or sterility. Some non-lethal plant diseases need to be controlled primarily to reduce the production of spores (e.g., that could infect alternate hosts), to reduce the amount of toxins in food products, or to improve the cosmetic appeal of crops to consumers. Silphium rust does not appear to infect sunflower and has not been reported to have alternate hosts outside of the genus. Seeds are generally free from rust pustules, meaning that grain quality/food safety is not a primary concern.

However, the negative effects of even moderately severe rust on silphium carbon and water budgets-and the challenge of controlling rust chemically—makes breeding for resistance a high priority. Silphium perfoliatum L. (cup plant) is nearly immune, at least to the populations of P. silphii naturally occurring in our breeding nurseries [39] (unpublished results). We have made interspecific crosses between S. perfoliatum and S. integrifolium to determine if non-host resistance alleles can be introgressed into $S$. integrifolium populations. We are also pursuing a multigenic "horizontal" resistance approach by including a leaf health score (primarily the absence of rust pustules) in our selection index along with seed and yield traits.

\subsection{Broader Implications}

Perennial crops are likely to capture more atmospheric carbon and soil water than annual crops by virtue of their longer growing season [40]. This proposition underlies two central rationales for investing in the development of perennial grains: (1.) It makes perennial grains possible: the extra carbon and water acquisition is necessary to support high allocation to harvested grain while simultaneously supporting additional plant "sinks" including overwintering storage organs [40]. (2.) This extra acquisition of carbon and water is acceptable or beneficial environmentally. For example, additional assimilated carbon should end up being sequestered belowground, helping to stabilize atmospheric carbon dioxide levels [41]. Water acquired from below the rooting zone of standard field crops should stabilize agroecosystem productivity during short-term droughts [42].

The efficient use of both carbon dioxide and water by perennial crops is necessary for either of these rationales. The evidence presented here suggests that foliar diseases can make a perennial plant highly inefficient with both acquired $\mathrm{CO}_{2}$ and $\mathrm{H}_{2} \mathrm{O}$, potentially undermining the very rationale for pursuing a new perennial crop. This finding illustrates the need for multidisciplinary domestication/perennialization teams to monitor changes occurring as the consequence of genetic selection and/or agroecosystem assembly [5]. 
A third rationale for perennial crops-that they are likely to be stress-tolerant-is based on the observation that wild perennial relatives of crops are often sources of genes for resistance to biotic and abiotic stress [43], perhaps because perennials have a history of natural selection for persistence. Perennial crops therefore could help farmers achieve goals of reduced dependence upon synthetic pesticides or other inputs. While we observe that Silphium integrifolium indeed resists many abiotic stresses and generalist herbivores [39], it is, or has become, highly susceptible to specialist pests and diseases, as shown here for the case of Puccinia silphii.

Specialists by definition have few, if any, alternate hosts / foods and are therefore under strong natural selection to overcome their host plant's defenses. Native prairie plants experience high rates of infestation compared with exotic plants [44]. We speculate that moving a wild plant from the forest or prairie may allow it to escape its enemies temporarily when initially evaluated at a research station. However, when grown in large numbers or in monocultures, native plants may become even more vulnerable than they were in the wild, as host abundance is correlated with prairie pathogen severity [45]. As with Silphium integrifolium, switchgrass (Panicum virgatum L.), another North American native perennial under domestication, was relatively unaffected by diseases during early research but the incidence of switchgrass rust (Puccinia emaculata) has increased and negatively impacted ethanol yield [46]. In light of this, we hypothesize that the yield of new perennial crops is more likely to be threatened by specialist than by generalist agricultural pests when first brought into cultivation. If this is true, the domestication of a perennial crop in its native range might be most efficient if aggressive research for managing specialist pests/pathogens were to precede investment in selection for classic domestication traits, even if few problems are initially observed. Alternatively, domestication could be done outside the range of these specialists.

Supplementary Materials: The following are available online at www.mdpi.com/2071-1050/10/3/696/s1, Figure S1: Rust scoring guide for silphium with pictorial examples.

Acknowledgments: We thank Eline van de Ven from the HAS University of Applied Sciences in the Netherlands for her substantial contribution in collecting and organizing data for the yield experiment. We gratefully acknowledge support from the Perennial Agriculture Project, a joint project between The Land Institute and The Malone Family Land Preservation Foundation.

Author Contributions: M. Kathryn Turner, Damian Ravetta and David Van Tassel conceived and designed the experiments; M. Kathryn Turner and Damian Ravetta performed the experiments; M. Kathryn Turner and Damian Ravetta analyzed the data; Damian Ravetta and David Van Tassel contributed reagents/materials/analysis tools; M. Kathryn Turner, Damian Ravetta and David Van Tassel wrote the paper.

Conflicts of Interest: The authors declare no conflict of interest. The Perennial Agriculture Project had no role in the design of the study; in the collection, analyses, or interpretation of data; in the writing of the manuscript, or in the decision to publish the results.

\section{References}

1. González-Paleo, L.; Ravetta, D.A. Relationship between photosynthesis, water use and leaf structure in desert annual and perennial forbs differing in growth. Photosynthetica 2018, 56. in press.

2. Jenks, M.A.; Joly, R.; Peters, P.J.; Rich, P.J.; Axtell, J.D.; Ashworth, E.N. Chemically Induced Cuticle Mutation Affecting Epidermal Conductance to Water Vapor and Disease Susceptibility in Sorghum bicolor (1.) Moench. Plant Physiol. 1994, 105, 1239-1245. [CrossRef] [PubMed]

3. Sevillano, M.; Del Ci, M.; D’ambrogioj, A.; Pastranai, C.P.; Sierrai, E. Resistance to rust caused by foliar pubescence in Argentinean common bean cultivars. Ann. Rep. Bean Improv. Coop. 1997, 40, 108-109.

4. Hol, W.H.G.; Van Veen, J.A. Pyrrolizidine alkaloids from Senecio jacobaea affect fungal growth. J. Chem. Ecol. 2002, 28, 1763-1772. [CrossRef] [PubMed]

5. Van Tassel, D.L.; Albrecht, K.A.; Bever, J.D.; Boe, A.A.; Brandvain, Y.; Crews, T.E.; Gansberger, M.; Gerstberger, P.; González-Paleo, L.; Hulke, B.S.; et al. Accelerating Domestication: An Opportunity to Develop New Crop Ideotypes and Breeding Strategies Informed by Multiple Disciplines. Crop Sci. 2017, 57, 1274. [CrossRef] 
6. Vilela, A.E.; González-Paleo, L.; Turner, M.K.; Peterson, K.E.; Ravetta, D.A.; Crews, T.E.; Van Tassel, D.L. Progress and observations during the early cultivation and domestication of Silphium integrifolium as a future perennial oilseed sunflower substitute. Sustainability 2018, 10, 638. [CrossRef]

7. Arthur, J.C. Manual of the Rusts in United States and Canada; Purdue research foundation: Lafayette, IN, USA, 1934.

8. Bolton, M.D.; Kolmer, J.A.; Garvin, D.F. Wheat leaf rust caused by Puccinia triticina. Mol. Plant Pathol. 2008, 9, 563-575. [CrossRef] [PubMed]

9. Caldwell, R.; Kraybill, H.; Sullivan, J.; Compton, L. Effect of leaf rust (Puccinia triticina) on yield, physical characters, and composition of winter wheats. J. Agric. Res. 1934, 48, 1049-1071.

10. Dyck, P.L.; Lukow, O.M. The genetic analysis of two interspecific sources of leaf rust resistance and their effect on the quality of common wheat. Can. J. Plant Sci. 1988, 68, 633-639. [CrossRef]

11. Everts, K.L.; Leath, S.; Finney, P.L. Impact of Powdery Mildew and Leaf Rust on Milling and Baking Quality of Soft Red Winter Wheat. Plant Dis. 2001, 85, 423-429. [CrossRef]

12. Scholes, J.D.; Farrar, J.F. Increased rates of photosynthesis in localized regions of a barley leaf infected with brown rust. New Phytol. 1986, 104, 601-612. [CrossRef]

13. Magyarosy, A.C.; Schurmann, P.; Buchanan, B.B. Effect of Powdery Mildew Infection on Photosynthesis by Leaves and Chloroplasts of Sugar Beets1. Plant Physiol. 1976, 57, 486-489. [CrossRef] [PubMed]

14. Bassanezi, R.B.; Amorim, L.; Filho, A.B.; Berger, R.D. Gas Exchange and Emission of Chlorophyll Fluorescence during the Monocycle of Rust, Angular Leaf Spot and Anthracnose on Bean Leaves as a Function of their Trophic Characteristics. J. Phytopathol. 2002, 150, 37-47. [CrossRef]

15. Lasko, A.; Pratt, C.; Pearson, R.C.; Pool, R.M.; Seem, R.C.; Welser, M.J. Photosynthesis, transpiration, and water use efficiency of mature grape leaves infected with Uncinula necator (powdery mildew). Phytopathology 1982, 72, 232-236.

16. Paul, N.D.; Ayres, P.G. Effects of rust and post-infection drought on photosynthesis, growth and water relations in groundsel. Plant Pathol. 1984, 33, 561-569. [CrossRef]

17. Gulya, T.; Venette, R.; Venette, J.R.; Lamey, H.A. Sunflower Rust; NDSU, Extension Service: Fargo, ND, USA, 1990.

18. Sackston, W.E. Studies on sunflower rust: III. Occurrence, distribution, and significance of races of Puccinia helianthi Schw. Can. J. Bot. 1962, 40, 1449-1458. [CrossRef]

19. Friskop, A.; Markell, S.G.; Khan, M. North Dakota Field Crop Fungicide Guide-PP622—Publications. Available online: https: / www.ag.ndsu.edu/publications/landing-pages/crops/north-dakota-field-cropfungicide-guide-pp-622 (accessed on 8 December 2017).

20. Fehr, W. Principles of Cultivar Development. Volume 1: Theory and Technique; Macmillion Publishing Co.: Ames, IA, USA, 1987.

21. Ravetta, D.A.; Goffman, F.; Pagano, E.; McLaughlin, S.P. Grindelia chiloensis resin and biomass production in its native environment. Indus. Crops Prod. 1996, 5, 235-238. [CrossRef]

22. Langenheim, J.H. Plant Resins: Chemistry, Evolution, Ecology, and Ethnobotany; Timber Press: Portland, OR, USA, 2003.

23. R Core Team. R: A Language and Environment for Statistical Computing; R Core Team: Vienna, Austria, 2014.

24. Gold, R.E.; Mendgen, K. Rust Basidiospore Germlings and Disease Initiation. In The Fungal Spore and Disease Initiation in Plants and Animals; Springer: Boston, MA, USA, 1991; pp. 67-99.

25. Parmelee, J.A. The Autoecious species of Puccinia on Heliantheae in North America. Can. J. Bot. 1967, 45, 2267-2327. [CrossRef]

26. Prasifka, J.R.; Mallinger, R.E.; Hulke, B.S.; Larson, S.R.; Van Tassel, D. Plant-Herbivore and Plant-Pollinator Interactions of the Developing Perennial Oilseed Crop, Silphium integrifolium. Environ. Entomol. 2017, 46, 1339-1345. [CrossRef] [PubMed]

27. Strong, F.E. Physiology of Injury Caused by Lygus hesperus. J. Econ. Entomol. 1970, 63, 808-814. [CrossRef]

28. Carretero, R.; Bancal, M.O.; Miralles, D.J. Effect of leaf rust (Puccinia triticina) on photosynthesis and related processes of leaves in wheat crops grown at two contrasting sites and with different nitrogen levels. Eur. J. Agron. 2011, 35, 237-246. [CrossRef]

29. Owera, S.; Farrar, J.; Whitbread, R. Growth and photosynthesis in barley infected with brown rust. Physiol. Plant Pathol. 1981, 18, 79-90. [CrossRef]

30. José Abad, M.; Miguel Bedoya, L.; Bermejo, P. Essential Oils from the Asteraceae Family Active against Multidrug-Resistant Bacteria. In Fighting Multidrug Resistance with Herbal Extracts, Essential Oils and Their Components; Elsevier: San Diego, CA, USA, 2013; pp. 205-221. 
31. Habermehl, G.; Fliegner, W. Terpenes and their Biological Relevance. In Studies in Natural Products Chemistry; Atta-ur-Rahman, Ed.; Elsevier Science: Amsterdam, The Nederland, 1998; pp. 3-24.

32. Stout, M.J. Host-Plant Resistance in Pest Management. In Integrated Pest Management; Elsevier: San Diego, CA, USA, 2014.

33. Salomon, M.V.; Purpora, R.; Bottini, R.; Piccoli, P. Rhizosphere associated bacteria trigger accumulation of terpenes in leaves of Vitis vinifera L. cv. Malbec that protect cells against reactive oxygen species. Plant Physiol. Biochem. 2016, 106, 295-304. [CrossRef] [PubMed]

34. Yoshitomi, K.; Taniguchi, S.; Tanaka, K.; Uji, Y.; Akimitsu, K.; Gomi, K. Rice terpene synthase 24 (OsTPS24) encodes a jasmonate-responsive monoterpene synthase that produces an antibacterial $\gamma$-terpinene against rice pathogen. J. Plant Physiol. 2016, 191, 120-126. [CrossRef] [PubMed]

35. Tanaka, S.; Brefort, T.; Neidig, N.; Djamei, A.; Kahnt, J.; Vermerris, W.; Koenig, S.; Feussner, K.; Feussner, I.; Kahmann, R. A secreted Ustilago maydis effector promotes virulence by targeting anthocyanin biosynthesis in maize. eLife 2014, 3, e01355. [CrossRef] [PubMed]

36. Zeneli, G.; Krokene, P.; Christiansen, E.; Krekling, T.; Gershenzon, J. Methyl jasmonate treatment of mature Norway spruce (Picea abies) trees increases the accumulation of terpenoid resin components and protects against infection by Ceratocystis polonica, a bark beetle-associated fungus. Tree Physiol. 2006, 26, 977-988. [CrossRef] [PubMed]

37. Rowe, H.C.; Ro, D.; Rieseberg, L.H. Response of Sunflower (Helianthus annuus L.) Leaf Surface Defenses to Exogenous Methyl Jasmonate. PLoS ONE 2012, 7, e37191. [CrossRef] [PubMed]

38. Van der Plank, J.E. Disease Resistance in Plants; Academic Press: Orlando, FL, USA, 1968.

39. Van Tassel, D.L.; The Land Institute, Salina, KS, USA. Personal communication, 2017.

40. DeHaan, L.R.; Van Tassel, D.L.; Cox, T.S. Perennial grain crops: A synthesis of ecology and plant breeding. Renew. Agric. Food Syst. 2005, 20, 5-14. [CrossRef]

41. Crews, T.; Rumsey, B. What Agriculture Can Learn from Native Ecosystems in Building Soil Organic Matter: A Review. Sustainability 2017, 9, 578. [CrossRef]

42. Glover, J.D.; Reganold, J.P.; Cox, C.M. Plant perennials to save Africa's soils. Nature 2012, 489, $359-361$. [CrossRef] [PubMed]

43. Glover, J.D.; Reganold, J.P.; Bell, L.W.; Borevitz, J.; Brummer, E.C.; Buckler, E.S.; Cox, C.M.; Cox, T.S.; Crews, T.E.; Culman, S.W.; et al. Agriculture. Increased food and ecosystem security via perennial grains. Science 2010, 328, 1638-1639. [CrossRef] [PubMed]

44. Han, X.; Dendy, S.P.; Garrett, K.A.; Fang, L.; Smith, M.D. Comparison of damage to native and exotic tallgrass prairie plants by natural enemies. Plant Ecol. 2008, 198, 197-210. [CrossRef]

45. Mitchell, C.E.; Tilman, D.; Groth, J.V. Effects of grassland plant species diversity, abundance, and composition on foliar fungal disease. Ecology 2002, 83, 1713-1726. [CrossRef]

46. Sykes, V.R.; Allen, F.L.; Mielenz, J.R.; Stewart, C.N.; Windham, M.T.; Hamilton, C.Y.; Rodriguez, M.; Yee, K.L. Reduction of Ethanol Yield from Switchgrass Infected with Rust Caused by Puccinia emaculata. BioEnergy Res. 2016, 9, 239-247. [CrossRef]

(C) 2018 by the authors. Licensee MDPI, Basel, Switzerland. This article is an open access article distributed under the terms and conditions of the Creative Commons Attribution (CC BY) license (http://creativecommons.org/licenses/by/4.0/). 